\title{
Review
}

\section{Molecular Mechanisms Underlying Female Sex Determination - Antagonism Between Female and Male Pathway}

\author{
Rafał P. PIPREK
}

Accepted April 20, 2009

\begin{abstract}
PIPREK R. P. 2009. Molecular mechanisms underlying female sex determination - antagonism between female and male pathway. Folia biol. (Kraków) 57: 105-113.

Molecular interactions in a developing gonad are crucial for an individual since they determine its phenotypic sex. The process of sex determination is complicated because of the antagonistic interactions between the male and female pathway. Factors responsible for the determination of femaleness make the female pathway. This pathway has to inhibit a complex network of male-determining factors and also has to induce the expression of genes that drive differentiation of the ovary. Morphological description of the ovary development suggests that this process is simple, however, the analysis of the robust gene expression indicates that genetic control of the ovary differentiation is active and complicated at the molecular level. A plethora of genes is expresed in developing gonads. Nevertheless, there are only a couple of genes the role in ovary development of which has been described till now. RSPO1 seems the main gene participating in the establishment of the ovary fate. The loss of functional R-spondin1 causes the complete female-to-male sex reversal in human. The second important factor is WNT4 which plays an opposite role to R-spondin 1 in the gonad but also is decisive for the ovarian fate. WNT4 and RSPO1 drive the disposition of $\beta$-catenin in cells and thus these factors regulate gene transcription and cell-cell adhesion. Foxl2 is another gene contributing to the development of the ovary. In females also germ cells seem to play important role in sex determination.
\end{abstract}

Key words: Sex determination, gonadal differentiation, follicular cells, germ cells, sex reversal, Rspol, Wnt4.

Rafat P. PIPREK, Department of Comparative Anatomy, Institute of Zoology, Jagiellonian University, R. Ingardena 6, 30-060 Kraków, Poland.

E-mail:rafalpiprek@wp.pl

Gonadal differentiation is controlled by molecular processes that act in developing gonads. There are two molecular pathways participating in sex determination. The female pathway that induces the expression of genes controlling development of the ovary and antagonizes the genes responsible for the testis development. While the male pathway, that is more complicated than the former, inhibits ovary development genes as well as up-regulates the expression of genes driving the testis differentiation.

Female sex in mammals has been considered the default (JOST 1947), which would nowadays imply that the basic pattern of gene expression in XX individuals is realized without a triggering signal. It is known that R-spondin1 and WNT4 signalling constitutes the main part of the molecular machinery of the female pathway (VAINIO et al. 1999;
MENKE \& PAGE 2002; YAO 2005; BERNARD \& HARLEY 2007; CHASSOT et al. 2008). In contrast, initiation of the male pathway driving testis development requires a triggering signal which is the SRY factor in almost all mammals (Fig. 1; POLANCO \& KOOPMAN 2007). Finally, it has been shown that ovarian development is also an active process which requires an inducing signal, similarly as the development of the testis. Recently, Rspondin 1 has been suggested as the most suitable primary female-determining factor diverting the gonad from the male to the female pathway in human and other vertebrates (CAPEL 2006; PARMA et al. 2006; SMITH et al. 2008). It has been revealed that this gene participates in sex determination in mammals (XX/XY system), birds (ZZ/ZW) and turtles with temperature-depending sex determination, which indicates that molecular basis of sex 
The female pathway The male pathway

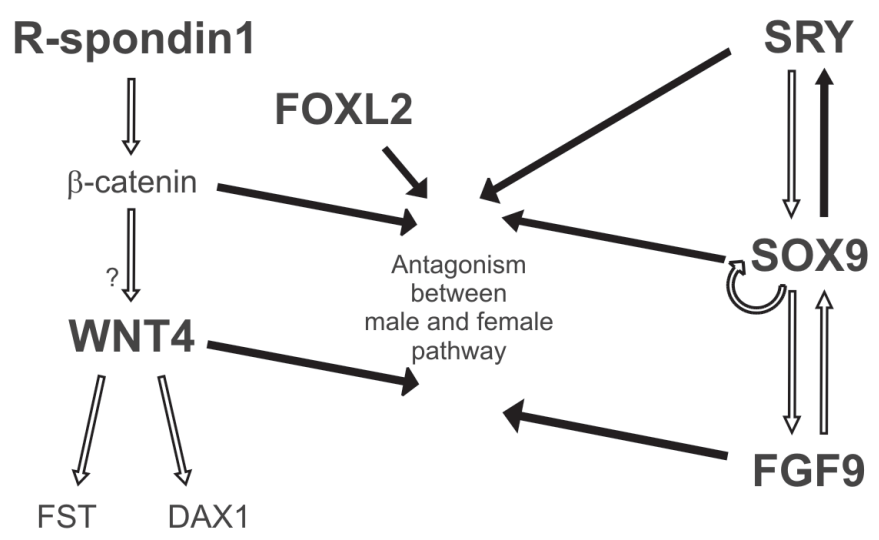

$\Longrightarrow$ activation $\longrightarrow$ inhibition

Fig. 1. Interactions between genes participating in mammalian sex determination.

$\mathrm{R}$-spondin1 signalling, engaging $\beta$-catenin stabilization, is the main part of the female sex-determining pathway (left). Direct targets of RSPO1 signalling remain unknown, however, WNT4 is downstream of RSPO1. Other ovary-specific factors, such as FST and DAX1, are downstream of WNT4. Foxl2 is expressed independently on Rspol and Wnt4. Both RSPO1 and WNT4 signalling as well as FOXL2 seem to inhibit the male pathway (right). SRY is the decisive factor in mammalian sex determination; it up-regulates Sox 9 and inhibits the female pathway by direct protein-protein interaction with $\beta$-catenin. There are a couple of positive feedback loops in the male pathway, owing to which the male pathway can up-regulate itself without SRY when the female pathway is impaired. Probably, also SOX9 and FGF9 signalling inhibit the female pathway.

determination is at least similar in animals with different sex-determining systems.

The female sex-determining pathway antagonizes the male pathway which seems more complicated and better-known than the former. In the male pathway the expression of Sry has to be induced in right place and time. Then SRY directly up-regulates the expression of $\operatorname{Sox} 9$ that induces $F g f 9$ expression. There are specific feedback interactions which ensure the male pathway and protect the gonad against the sex reversal. One of two sex-determining pathways has to be up-regulated compatibly with genetic sex. If germ cells are placed in a sex reversed gonad, their genetic sex will be opposite to gonadal sex, which will cause disturbance during spermatogenesis or oogenesis. This indicates that gonadal sex has to be compatible with genetic sex. A lack of compatibility is the direct cause of infertility in disorders such as complete sex reversal or hermaphroditism.

The male pathway can be relatively easily disrupted during the gonadogenesis but is very stabile after the onset of testis differentiation period when the structure of the testis is established. Such a testis is not susceptible for sex reversal. However, the female pathway is not easily impaired during the sex-determining period, which is proved by the fact that male-to-female sex reversal is more frequent than female-to-male sex reversal in human. Nevertheless, the structure of the adult ovary can be easily reversed due to trans-differentiation into the testis. It indicates that the nature of the female pathway is different than the male pathway and there are specific molecular interactions in the testis that prevent against sex reversal.

RSPO1, WNT4 and FOXL2 - factors crucial for the ovary fate

The culminate event in female sex determination takes place when Rspol and Wnt 4 begin to be upregulated in XX gonadal cells, which occurs at $11.5 d p c$ in mice, however, the significant expression of ovarian markers is observed at $12.5 \mathrm{dpc}$ when other factors, such as FOXL2, may contribute to female sex determination (VAINIO et al. 1999; PARMA et al. 2006; OTTOLEGHI et al. 2007).

Initial data indicated that the genetic control of ovarian differentiation is based on Wnt4 pathway that up-regulates the expression of Daxl, Fst (follistatin), Bmp2 and other ovary-specific genes (Fig. 1; MizUSAKI et al. 2003; YAO et al. 2004). Mutations in Wnt4 do not result in primary sex reversal in XX, while masculinization in XX mice and in a female patient results from an increased testosterone level due to an increase in number of steroidogenic cells migrating from adrenal glands to the gonads (HEIKKILA et al. 2005). Wnt4 is expressed in both XX and XY bipotential gonads, 
which may be needed to suppress steroidogenic cells differentiation or rather the migration of their precursors inwards the gonad since $\mathrm{Wnt}^{-4^{-/}}$mutants reveal steroidogenesis already at $11.5 d p c$ (JEAYS-WARD et al. 2004). Moreover, XX Wnt4-null mutants show male-specific mesonephric cell migration to the gonad and the formation of testis-specific coelomic vessel. Male-specific migration of mesonephric-derived cells inwards the XX gonad has to be inhibited by the female pathway since these cells up-regulate the expression of testis markers in XX gonads (TILMANN \& CAPEL 1999). One research has shown that $F g f 9$ and $\operatorname{Sox} 9$ are up-regulated in gonads of XX Wnt4 ${ }^{-/-}$mutants, which indicates that $W n t 4$ can be important for female sex determination because this gene antagonizes the testis pathway possibly by the inhibition of $F g f 9$ expression (KIM et al. 2006a). Interestingly, overexpression of Wnt4 in XY gonads impairs steroidogenesis and development of testis-specific vasculature (JORDAN et al. 2003). Nevertheless, Wnt4 is needed for up-regulation of Sox9 in XY and thus for proper male sex determination since Sox9 expression is impaired in $\mathrm{Wnt}^{-/-} \mathrm{XY}$ gonads while Sry expression is not altered (JEAYS-WARD et al. 2004).

The disruption in Wnt4 expression does not result in primary sex reversal, which implies that WNT4 may not be the primary and main component of the female pathway and another gene may encode the primary female-determining factor. It was thought that this hypothesis had been solved owing to research into an Italian family. Some males in this family are XX, displaying a complete sex reversal, furthermore they have a predisposition to palmoplantar hyperkeratosis and squamous cell carcinoma of the skin (PARMA et al. 2006). Genomic research revealed an insertion of one guanine in the fourth codon of exon 5 in the gene RSPO1, linked to chromosome 1 . This mutation results in a frameshift and stop codon, and as a consequence, in abolition of all normal isoforms of R-spondin1. In another family one XX male patient revealed a deletion of exon 4 and thus also affected all isoforms of R-spondin1 (PARMA et al. 2006). Thus, R-spondin 1 has been suggested as the primary female-sex determining factor that stands at the top of the ovary pathway (CAPEL 2006). There is also described mutation in human RSPO1 that leads to aberrant splicing, which causes translation of Rspol mRNA into a partially functioning protein and as a result development of both testicular and ovarian tissue in gonads and XX true hermaphroditism (partial sex reversal) (TOMASELLI et al. 2008).

$\mathrm{R}$-spondins are a small family of growth factors that participate, via frizzled (FZD) receptor, in regulation of development of some structures by stabilization of $\beta$-catenin. Thus, RSPO signalling leads to an increase of $\beta$-catenin in cytosol and nu- cleus and enables to the regulation of gene expression since $\beta$-catenin functions in cooperation with $\mathrm{TCF} / \mathrm{LEF}$ as a transcription factor in the nucleus (KIM et al. 2006b; NAM et al. 2006). Furthermore, R-spondin1 enhances WNT action by increasing LRP6 levels on the cell surface; LRP6 is a coreceptor required for WNT signalling (BINNERTS et al. 2007). Interestingly, LRP6 ablation has been associated with abnormal ovary development (PINSON et al. 2000). WNT4 has appeared to relocate $\beta$-catenin to the cell membrane where catenins are associated with cadherins contributing to cell adhesion (BERNARD et al. 2008a). It indicates that R-spondins can active WNT signalling, nevertheless, WNT4 seems to contribute to a decrease of $\beta$-catenin in cytosol and nucleus and thus WNT4 signalling can interfere with the female pathway. R-spondin 1 and WNT4 seem to act on the same cells since these signalling proteins are localized around both somatic and germ cells in cortical region of early differentiating goat ovary. At latter stages these proteins become localized on the germ cell membranes (KOCER et al. 2008). Rspol is expressed in both somatic and germ-line cells in the goat ovary, which can explain the role of germ cells in development of the ovary. While in mouse Rspol is expressed in somatic cells and little in germ cells (SMITH et al. 2008). Also in mice RSPO1 protein is detected in the cytoplasm and at the cell surface of somatic and germ cells throughout the XX gonads, not only in cortical region. $\beta$-catenin, as an executive factor in the female pathway, is detected in the cytoplasm and nuclei of $\mathrm{XX}$ gonadal cells, while in XY this protein is concentrated rather close to the cell membrane (CHASSOT et al. 2008).

The lack of properly acting R-spondin1 leads to significant impairment in concentration of $\beta$-catenin in cytosol and nucleus in XX gonad (CHASSOT et al. 2008), which enables the male pathway to up-regulate itself and as a result diverts the XX gonad from ovarian to testicular differentiation. Two researches have shown that the deletion of murine Rspol results only in partial sex reversal similar to the sex reversal in $W n t 4^{-/} \mathrm{XX}$, which is consistent with the disruption of Wnt4 expression in Rspo 1-null mutants (CHASSOT et al. 2008; TOMIZUKA et al. 2008). Ovotestes in XX Rspol ${ }^{-/-}$ display ectopic synthesis of testosterone, probably by adrenal-derived cells, and the coelomic vessel formation at $12.5 d p c$ by the loss of Wnt 4 expression. Moreover, development of germ cells is impaired. And only several testis cords are formed at $18.5 \mathrm{dpc}$, indicating an insufficient activation of testis-markers. Importantly, the depletion of $\beta$-catenin in SF1-positive cells in XX gonads results in almost identical phenotypes as in $\operatorname{Rspol}^{-/-}$and $W n t 4^{-/ 2}$. Moreover, the expression of Rspol is not 
altered in the lack of $\beta$-catenin, however, $W n t 4$ and $F s t$ are down-regulated in such XX gonads $(\mathrm{H}$. H. YAO, personal communication). Rspol is normally expressed in Wnt4-deleted ovaries while Wnt4 expression is disrupted in Rspol-null mutants, thus Rspol is upstream of Wnt4. Among ovary-specific genes, the expression of Bmp2 and Foxl2 is not altered, however, Fst, Wnt4 and Wnt $9 a$ are downregulated in Rspol $^{-/-}$. Activation of Axin2, that is a target of $\beta$-catenin, is not detected in XX Rspo $1^{-/-}$ at $13.5 \mathrm{dpc}$ while is observed in $\mathrm{XX} \mathrm{Wnt}^{-/-}$, which indicates that activation of $\beta$-catenin in the ovary depends on RSPO1 and not on WNT4 (CHASSOT et al. 2008). Interestingly, ectopicly enhanced activation of $\beta$-catenin prevents sex reversal in XX Rspol-depleted ovary. Above data imply that Rspol is a good candidate for the primary sexdetermining gene in mammals and the lack of complete sex reversal results from the action of other ovary-determining factors. Additionally, Rspondin 1 up-regulates $W n t 4$ via $\beta$-catenin and participates in suppression of the male pathway.

Localization of $\beta$-catenin overlaps with RSPO1 and WNT4 in germinal and somatic cells in cortical region of goat differentiating ovary (KOCER et al. 2008). RSPO1 and WNT4 are observed on the germ cell membrane (KOCER et al. 2008). In addition, meiosis is impaired in Rspol-null mutants as well as in the XX gonads devoid of $\beta$-catenin in somatic cells (CHASSOT et al. 2008; H. H. YAO, personal communication). Normally, E-cadherins, associated with $\beta$-catenin and cell-cell adhesion, are down-regulated in XX germ cells during entering into meiosis. Thus, RSPO1 and WNT4 can influence XX germ cell development, their maintenance and entering into meiosis. Wnt 4 is down-regulated in the ovary close to $14.5 \mathrm{dpc}$, which impairs redirection of $\beta$-catenin to the cell membrane and thus alters germ cell adhesion. It is required for entering into meiosis. An additional anti-testis factor may be needed during inactivation of WNT4 signalling in order to prevent activation of the male pathway.

Duplication of a part of the short arm of human chromosome 1 (dup1p31-35), including RSPO1 (1p34.3), did not cause complete sex reversal in an XY patient (ELEJALDE et al. 1984). It implies that there are probably specific regulatory sequences or another gene at the top of the female-sex determination cascade since a duplication of a part of human chromosome 1 (dup1p22.3-32.3), excluding WNT4 $(1 \mathrm{p} 35)$ and $R S P O 1$, results in complete male-to-female sex reversal in humans (WIEACKER \& VOLLETH 2007).

It has been suggested that FOXL2, which acts as a forkhead transcription factor, may be an ovarydetermining factor since its mutation is involved in XX sex reversal in goats and in depletion of ovarian follicles in mice and humans (CRISPONI et al.
2001; HARRIS et al. 2002; PAILHOUX et al. 2002; UDA et al. 2004). Foxl2 is expressed in mouse gonad from $11.5 d p c$ and null-mutation in this gene results in derepression of the male pathway in the ovary in perinatal period (OTTOLENGHI et al. 2005). However, loss of both Foxl2 and Wnt4 leads to significant activation of the male pathway in fetal XX gonads (OTTOLENGHI et al. 2007). Thus, Foxl2, like Wnt4, is an anti-testis but not primary ovary-determining factor. Foxl2 is up-regulated in XX gonads in the medullar region of the goat ovary in sex determination period ( $40 d p c$ ), however, FOXL2 is absent in cortical region where Rspondin 1 and WNT4 are detected. At later stage FOXL2 is detected in the medulla as well as the cortex of the goat gonad (KOCER et al. 2008). Maybe the spreading expression of Foxl2 prevents sex reversal when Wnt4 is inactivated during the onset of the meiosis. Null-mutation in goat Foxl2 does not alter the expression of Rspol and Wnt4 but leads to decrease in RSPO2 level (KOCER et al. 2008). In addition, the expression of Foxl2 is not disrupted in Rspol $^{-/ 2}$ mouse (CHASSOT et al. 2008), which indicates the presence of more than one independent ovary-determining pathways.

RSPO1 and WNT4 can act as paracrine factors that promote ovarian cell differentiation. The mesonephros is the source of a large amount of WNTs expressed in murine embryonic kidney from 9.5 dpc onwards (STARK et al. 1994). In addition, RSPO1 is synthesised in goat mesonephroi (KOCER et al. 2008). These signalling molecules can possibly diffuse short distances (a few cell diameters) towards the gonad and change gene expression. It may explain the increased level of expression of the ovarian pathway genes, such as Wnt4 and Daxl, initially observed in the gonadal region facing the mesonephros (KIM et al. 2006a). It would be interesting to determine whether molecules secreted in the mesonephros influence sex determination and/or gonad development. The observation of gene expression in $\mathrm{Wnt}^{-/ /}$mice carrying the Wnt4 gene driven by the SF1 promoter (SF1:Wnt4 transgene) confirms this hypothesis. Such XY mice exhibit Wnt4 expression only in gonads and adrenal precursors. The lack of mesonephric WNT4 causes the impairment of the Sertoli cell phenotype and an increase in Cyp 1 1al expression (JEAYS-WARD et al. 2004). This suggests that signalling molecules, such as WNT4 and RSPO1 derived from the mesonephros, may contribute to sex determination and/or gonadal differentiation.

The antagonism between the male and female pathway

The main challenge in male sex determination is the incitement of the testicular pathway to the ex- 
tent that its factors reach a high concentration at the right time just prior to the onset of the ovarian pathway up-regulation. The following point of sex determination constitutes the conflict between the testicular and ovarian pathways, which is needed to prevent the opposite sex pathway from taking control over gonadal development. It may be said that the female pathway has no impediments in the control of XX gonad differentiation because the lack of Sry prevents the up-regulation of $\operatorname{Sox} 9$ expression. Nevertheless, it is not true since vestigial quantities of $\mathrm{SOX} 9, \mathrm{FGF} 9$ and prostaglandin $\mathrm{D}_{2}$ in XX gonads can result in the release of the male pathway due to the incitement of a positive feedback loop between these testis-specific factors. Thus, the signal of female sex determination also needs to be robust in order to prevent the male pathway from diverting the gonad from ovarian to testicular differentiation. Moreover, the female pathway has to be maintained since the male pathway can release itself and lead to sex reversal even after birth. Impaired genetic control of ovary differentiation enables Sox 9 and $F g f 9$ to up-regulate each other without contribution of SRY, which is the cause of female-to-male sex reversals. Importantly, it has been shown that SRY, as well as SOX9, reduces the intracellular concentration of $\beta$-catenin in vitro (BERNARD et al. 2008b). It indicates that the pivotal factors of the male pathway can inhibit the female pathway by the direct protein-protein interactions.

Some specific molecular interactions confirm the antagonism between the female and male pathway that is the basis of sex determination. For example, ectopic FGF9 blocks expression of Wnt4 in $\mathrm{XX}$ gonads in vitro. Nevertheless, ectopic FGF9 is able to induce the male pathway in XX gonad when a level of WNT4 is altered. Null-mutants $\mathrm{FgfO}^{-/ 2}$ show Wnt4 up-regulation in XY gonads at $12.5 \mathrm{dpc}$. Additionally, the lack of WNT4 leads to up-regulation of Sox9 and Fgf9 in XX gonads (KIM et al. 2006a). Thus, it has been suggested that the antagonism between FGF9 and WNT4 can be the main part of sex determination and that SOX9 has a minor contribution in this conflict due to the observation that FGF9, rather than SOX9, inhibits Wnt4 expression (KIM \& CAPEL 2006). $\beta$-catenin binds to transcription factors, such as TCF and LEF, and thus drives changes in the gene expression. TCF and LEF are rated among the SOX gene family since they contain the HMG domain and bind to WACAAW sequences. It implies that the executive complex of the female sex-determining pathway can bind to the same sequences that SRY and SOX9 bind to. Such a competition for targets may be the main part of sex determination. Interestingly, Lefl is up-regulated in the developing ovary (CHASSOT et al. 2008). Potentially, $\beta$-ca- tenin with co-factors may bind the promoter of $F g f 9$ and inhibit its expression. However, the derepression of the expression of $F g f 9$ is retarded and observed in $14.5 \mathrm{dpc}$ in $\mathrm{XX} \mathrm{Rspo1^{-/- }}$ mice, which is associated with the absence of the early testisspecific proliferation (CHASSOT et al. 2008). Maybe $\beta$-catenin directly influences the expression of the Sox9 gene since this protein binds to the regulatory regions of Sox 9 during development of other structures. It is supported by the early upregulation of Sox9 expression in XX Rspol ${ }^{-/-}$at 12.5 dpc (CHASSOT et al. 2008), which may be caused by prostaglandin $\mathrm{D}_{2}$ secreted by germ cells since XX germ cell fate is altered in the ablation of RSPO1. Moreover, $\beta$-catenin signalling possibly may lead to degradation of male-specific factors. In contrast, SOX9 and/or signalling effectors of the FGF9 pathway may bind to $\beta$-catenin and block its action. This is confirmed by the observed co-immunoprecipitation of SOX9 and $\beta$-catenin during chondrogenesis, which inhibits WNT/ $\beta$-catenin signalling (AKIYAMA et al. 2004; KIM \& CAPEL 2006). The antagonism between $\beta$-catenin signalling versus SOX9 and FGF9 pathway acts during the differentiation of mesenchymal progenitors into osteoblasts or chondrocytes (DAY et al. 2005; HILL et al. 2005). In this process SOX9 is co-localized with $\beta$-catenin (AKIYAMA et al. 2004). In addition, SOX and $\beta$-catenin interaction is involved in the molecular control of the development of other structures, such as mesoderm and axis formation (ZORN et al. 1999). Finally, it appeared that SRY as well as SOX9 reduce the intracellular concentration of $\beta$-catenin in vitro (BERNARD et al. 2008b). It indicates that the pivotal factors of the male pathway can inhibit the female pathway by the direct protein-protein interactions.

Rspol and Wnt4 are expressed in both XX and $\mathrm{XY}$ bipotential gonads and the ovary-specific upregulation of these genes takes place between 11.5 and $12.5 \mathrm{dpc}$ in mice (JEAYS-WARD et al. 2003; NEF et al. 2005; PARMA et al. 2006). This onset of the femalespecific gene expression should be strictly controlled, similarly to Sry expression. It has been shown that WT1-KTS up-regulates Wnt4 (SIM et al. 2002). In addition, inhibitors of cyclindependent kinase, such as p63 and p73, belonging to the p53 tumour suppressor gene family, bind to the Wnt4 promoter and activate expression of this gene in human embryonic kidney cells (OSADA et al. 2006). Moreover, genes of this family, such as $p 21, p 27$ and $p 57$, are over-expressed in differentiating ovaries (NEF et al. 2005), probably downstream of Wnt 4 and/or Rspo 1. However, p21 binds and represses the Wnt4 promoter in synergy with transcription factor E2f1 which may be engaged in the testis pathway due to the observation that E2f1 up-regulates $F g f r 2$ expression (TASHIRO et al. 
2003; DEVGAN et al. 2005; BERNARD \& HARLEY 2007). Since inhibitors of cycline-dependent kinases are downstream of the female pathway, there may be a positive feedback loop that enhances the female pathway. It seems that the time of the onset of expression of Rspol and Wnt4 in the XX gonad is essential for for female-sex determination since it makes the release of the male pathway impossible. However, ovary-specific genes cannot be expressed too early since it could leads to increase a level of female factors also in XY, which could impair testis development. The accelerated switch of the ovary pathway would cause a high concentration of DAX1 in the XY gonad, which interferes in the male pathway probably by excessive downregulation of $S f 1$ responsible for Sry up-regulation; moreover, SRY would not induce Sox9 early enough, so SOX9 and FGF9 would not reach the high concentrations required to inhibit expression and/or action of Wnt4 and Rspol. It is important that the factors encoded by these genes reach a high concentration in order to inhibit Sox 9 and Fgf9 expression and/or their action. It can be assumed that the onsets of ovarian and testicular pathways have to be synchronized so that gonadogenesis is correct. The acceleration or retardation in the pathway of one sex would lead to sex reversal, which may be the cause of sexual development disorders in humans. Such disturbances in timing may result from a mixing of genetic backgrounds as in mice, and from mutation in regulatory genes.

The role of germ cells and steroid hormones in sex determination

Observations on sterile gonads have shown that there are little-known interactions between the somatic and germ cells. Germ cells have appeared necessary for the maintenance of ovary structure. Nevertheless, germ cells are unimportant for the persistence of testis structure. The lack of germ cells in early ovaries results in the absence of the formation of ovarian follicles, however, the apoptosis of germ cells in older ovaries leads to rapid degeneration of follicles and to appearance of testis-specific structures following testis structures (MCLAREN 1984; BEHRINGER et al. 1990; HASHIMOTO et al. 1990; COUSE et al. 1999).

There are some mutations and factors described that lead to the loss of germ cells. The absence of germ cells in XX gonads results in the occurrence of sex reversal symptoms. Null-mutations in Wnt4, Rspol, Foxl2 and Fst enhance the process of oocyte degeneration (VAINIO et al. 1999; YAO et al. 2004). The loss of XX germ cells leads to cordlike structure formation, causing the $\mathrm{XX}$ gonad to resemble a testis, which may suggest secondary sex reversal. The expression of testis markers has been observed at birth in mice deprived of Wnt4 (VAINIO et al. 1999). Similarly, a depletion of murine Foxl2 causes the loss of germ cells subsequently to the derepression of the male pathway in the XX gonad soon after birth (OTTOLENGHI et al. 2005). This indicates a direct role for FOXL2 in the suppression of the male pathway in the female gonad. Also, depletion of Fig, the gene required for zona pellucida formation and expressed in germ cells, results in a lack of ovarian follicle formation, which leads to apoptosis of oocytes after birth. In such XX gonads cord-like structures are visible (SOYAL et al. 2000). Similar secondary sex reversal resulting from the loss of germ cells has been observed in ovaries cultured with testes or with $\mathrm{AMH}$, in busulfan-treated rat, in $W / W v$ mice, in utero irradiated rats, in mice over-expressing Amh and in ovary after long-term culture in a basic medium alone (reviewed by GUIGON \& MAGRE 2006).

Interestingly, the absence of estrogens or the lack of the capacity to respond to estrogen resulting from a loss-of-function mutation in aromatase encoding gene (ArKO) or double null-mutation in and estrogen receptors (ERKO), leads to the loss of germ cells, which causes degeneration of ovarian follicles. The follicular cells do not die but begin to express testis marker genes, such as Sox9, Amh, which suggests that these cells trans-differentiate into Sertoli cells. Moreover, seminiferous tubulelike structures and Leydig cells appear in such trans-differentiating XX gonads (COUSE et al. 1999; DUPONT et al. 2000, 2003; BRITT et al. 2002, 2004; BRITT \& FINDLAY 2003). Ectopic estrogens can suppress trans-differentiation or can even reverse newly formed Sertoli cells (BRITT et al. 2002). This secondary sex reversal of supporting cell lineages takes place after puberty, which indicates that estrogens are required for maintenance of the female pathway but are not essential for female sex determination nor ovarian differentiation. Interestingly, sex steroid administration as well as testis transplantation cause Sertoli cell differentiation in gonads of XX murine foetuses (TAKETO et al. 1984; TAKETO-HOSOTANI et al. 1985; HASHIMOTO et al. 1990). This suggests that the female pathway is sensitive to sex steroids. On the other hand, the male pathway, mainly among placental mammals, is insensitive to estrogens, which is an adaptation to the uterine environment. Signs of ovary trans-differentiation into testis are observed also in female freemartin cattle, aging female mice and postmenopausal women (CHAPIN 1917; LILlie 1917; CRUMEYROLle-ARIAS 1976; SCULLY 1979; BRITT et al. 2002). Also the low level of estrogens in postmenopausal women associated with the degeneration of follicles in ovaries 
may be the reason of trans-differentiation of follicular cells into Sertoli-like cells.

It can be assumed that the presence of germ cells is essential for maintenance of follicles and suppression of Sertoli cell fate after ovarian differentiation. Factors such as WNT4, follistatin, and estrogens are crucial for prevention of apoptosis of germ cells and thus rescue ovary existence. On the contrary, the absence of germ cells in the testis does not alter its differentiation, thus the testis does not require germ cells to maintain its pathway. Nevertheless, germ cells in XY gonads produce prostaglandin $\mathrm{D}_{2}$ and thus support the maintenance of the male pathway, however, the lack of germ cells only delays testis cord formation (MERCHANT 1975; ADAMS \& MCLAREN 2002; YAO et al. 2003).

In conclusions it can be assumed that upregulation of Rspol and $\mathrm{Wnt} 4$ expression is probably the pivotal part of the female sex-determining pathway. Null-mutations in these genes result in symptoms of sex reversal in mouse as well as in human. In addition, Foxl2 has appeared another gene participating in sex determination. Studies have shown that Rspol is upstream of Wnt4 and these genes are presumably independent on Foxl2 (Fig. 1). R-spondin 1 acts as paracrine factor increasing the cytosolic concentration of $\beta$-catenin that regulates transcription of other genes. Probably, $\beta$-catenin induces the expression of genes driving ovarian differentiation and inhibits the expression of genes involved in testis development. It is supposed that there are a couple of controlling points in sex determination where the female and male pathways antagonize each other. Probably, SOX9, FGF9 and $\beta$-catenin are important factors in this antagonism (Fig. 1).

Now it is clear that the testis structure is stabile and its maintenance is independent on sex hormones nor the presence of germ cells. However, the structure of the adult ovary can be lost and reversed when the male pathway up-regulates after the sex-determining period in XX gonad. Estrogens as well as the presence of female germ cells are needed to protect against the female-to-male sex reversal.

\section{References}

ADAMS I. R., MCLAREN A. 2002. Sexually dimorphic development of mouse primordial germ cells: switching from oogenesis to spermatogenesis. Development 129: 1155-1164.

AKIYAMa H., LYONS J. P., MORI-AKIYAMA Y., YANG X., ZHANG R., ZHANG Z., DENG J. M., TAKETO M. M., NAKAMURA T., BEHRINGER R. R., MCCREA P. D., DE CROMBRUGGHE B. 2004. Interactions between Sox9 and beta-catenin control chondrocyte differentiation. Genes Dev. 18: 1072-1087.
BEHRinger R. R., CATE R. L., Froelick G. J., PALmiter R. D., BRINSTER R. L. 1990. Abnormal sexual development in transgenic mice chronically expressing Müllerian inhibiting substance. Nature 345: 167-170.

Bernard P., Fleming A., Lacombe A., Harley V. R., VILAIN E. 2008a. Wnt4 inhibits $\beta$-catenin/TCF signalling by redirecting $\beta$-catenin to the cell membrane. Biol. Cell 100: 167-177.

BERNARD P., HARLEY V. R. 2007. Wnt4 action in gonadal development and sex determination. Int. J. Biochem. Cell. Biol. 39: 31-43.

Bernard P., Sim H., KNOWER K., Vilain E., Harley V. 2008b. Human SRY inhibits $\beta$-catenin-mediated transcription. Int. J. Biochem. Cell. Biol. 40: 2889-2900.

Binnerts M. E., KiM K., BRight J. M., PATEl S. M., TRAN K., ZHOU M., LEUNG J. M., LIU Y., LOMAS III W. E., DIXON M., Hazell S. A., Wagle M., Nie W., Tomasevic M., Williams J., Zhan X., LeVy M. D., FunK W. D., ABo A. 2007. R-Spondin1 regulates Wnt signaling by inhibiting internalization of LRP6. Proc. Natl Acad. Sci. U.S.A. 104: 14700-14705.

BritT K. L., KerR J., O’DONELl L., JONES M. E., DruMMOND A. E., DAVIS S. R., SimPSON E. R., FINDLAY J. K. 2002. Estrogen regulates development of the somatic cells phenotype in the eutherian ovary. FASEB J. 16: 1389-1397.

Britt K. L., Stanton P. G., Misso M., Simpson E. R., FINDLAY J. K. 2004. The effects of estrogen on the expression of genes underlying the differentiation of somatic cells in the murine gonad. Endocrinology 145: 3950-3960.

BRITT K. L., FINDLAY J. K. 2003. Regulation of the phenotype of ovarian somatic cells by estrogen. Mol. Cell. Endocrinol. 202: 11-17.

CAPEL B. 2006. R-spondin1 tips the balance in sex determination. Nat. Genet. 38: 1233-1234.

Chapin C. L. 1917. A microscopic study of the reproductive system of fetal freemartins. J. Exp. Zool. 23: 453-482.

Chassot A. A., Ranc F., Gregoire E. P., Roepers-GAJADIEN H. L., TAKETO M. M., CAMERINO G., DE ROOIJ D. G., SCHEDL A., CHABOISSIER M. C. 2008. Activation of $\beta$-catenin signaling by Rspol controls differentiation of the mammalian ovary. Hum. Mol. Genet. 17: 1264-1277.

Couse J. F., HewitT S. C., Bunch D. O., SAR M., WalKer V. R., DAVIS B. J., KORACH K. S. 1999. Postnatal sex reversal of the ovaries in mice lacking estrogen receptors alpha and beta. Science 286: 2328-2331.

Crisponi L., Deiana M., Loi A., Chiappe F., UdA M., Amati P., Bisceglia L., Zelante L., NAgaraja R., PORCU S., Ristaldi M. S., Marzella R., ROCCHI M., NicOLINO M., LIENHARDT-ROUSSIE A., NIVELON A., VERLOES A., SCHLESSINGER D., GASPARINI P., BONNEAU D., CAO A., PILIA G. 2001. The putative forkhead transcription factor FOXL2 is mutated in blepharophimosis/ptosis/epicanthus inversus syndrome. Nat. Genet. 27: 159-166.

Crumeyrolle-Arias M., Scheib D., AschHeim P. 1976. Light and electron microscopy of the ovarian interstitial tissue in the senile rat: normal aspect and response to HCG of 'deficiency cells' and 'epithelial cords'. Gerontology 22: 185-204.

Day T. F., Guo X., Garrett-Beal L., Yang Y. 2005. Wnt/beta-catenin signalling in mesenchymal progenitors controls osteoblast and chondrocyte differentiation during vertebrate skeletogenesis. Dev. Cell 8: 739-750.

Devgan V., Mammucari C., Millar S. E., Brisken C., DOTTO G. P. 2005. p21WAF1/Cip1 is a negative transcriptional regulator of Wnt4 expression downstream of Notch1 activation. Genes Dev. 19: 1485-1495.

Dupont S., DENNEFELD C., KRUST A., CHAMBON P., MARK M. 2003. Expression of Sox9 in granulosa cells lacking the estrogen receptors, ERalpha and ERbeta. Dev. Dyn. 226: 103-106.

Dupont S., Krust A., Gansmuller A., Dierich A., CHAMBON P., MARK M. 2000. Effect of single and compound knockouts of estrogen receptors alpha (ERaphfa) and 
beta (ERbeta) on mouse reproductive phenotypes. Development 127: 4277-4291.

Elejalde B. R., Opitz J. M., DE Elejade M. M., Gilbert E. F., Abellera M., Meisner L., Lebel R. R., Hartigan J. M., BREG W. R. 1984. Tandem dup (1p) within the short arm of chromosome 1 in a child with ambiguous genitalia and multiple congenital anomalies. Am. J. Med. Genet. 17: 723-730.

GuigOn C. J., MAGRE S. 2006. Contribution of germ cells to the differentiation and maturation of the ovary: Insights from models of germ cell depletion. Biol. Reprod. 74: 450-458.

HARRIS S. E., CHAND A. L., WINSHIP I. M., GERSAK K., AITTOMAKI K., SHELLING A. N. 2002. Identification of novel mutation in Foxl2 associated with premature ovarian failure. Mol. Hum. Reprod. 8: 729-733.

Hashimoto N., KuboKawa R., YamaZaki K., NoguchI M., KATO Y. 1990. Germ cells dificiency causes testis cord differentiation in reconstituted mouse fetal ovaries. J. Exp. Zool. 253: 61-70.

Heikkila M., Prunskaite R., Naillat F., Itaranta P., VuORISTO J., LePPAluoto J., Peltoketo H., VAinio S, 2005. The partial female to male sex reversal in Wnt4dificient females involves induced expression of testosterone biosynthetic genes and testosterone production, and depends on androgen action. Endocrinology 146: 4016-4023.

Hill T. P., Spater D., Taketo M. M., Birchmeier W., HARTMANN C. 2005. Canonical Wnt/beta-catenin signalling prevents osteoblasts from differentiating into chondrocytes. Dev. Cell 8: 727-738.

JEAYS-WARD K., DANDONNEAU M., SWAIN A. 2004. Wnt4 is required for proper male as well as female sexual development. Dev. Biol. 276: 431-440.

Jeays-Ward K., Hoyle C., Brennan J., Dandonneau M., ALLDUS G., CAPEL B., SWAIN A. 2003. Endothelial and steroidogenic cell migration are regulated by WNT4 in the developing mammalian gonad. Development 130: 3663-3670.

Jordan B. K., Shen J. H., Olaso R., Ingraham H. A., VILAIN E. 2003. Wnt4 overexpression disrupts normal testicular vasculature and inhibits testosterone synthesis by repressing steroidogenic factor $1 /$ beta-catenin synergy. Proc. Natl Acad. Sci. U.S.A. 100: 10866-10871.

KIM Y., CAPEL B. 2006. Balancing the bipotential gonad between alternative organ fates: a new perspective on an old problem. Dev. Dyn. 235: 2292-2300.

KIM Y., KoBAYASHI A., SEKIDO R., DinAPOLI L., BRENNAN J., Chaboissier M. C., Poulat F., BeHringer R. R., LOVELL-BADGE R., CAPEL B. 2006a. Fgf9 and Wnt4 act as antagonistic signals to regulate mammalian sex determination. PLoS Biol. 4: e187.

Kim K. A., ZhaO J., ANDARMANi S., KAKITANI M., OSHIMA T., BINNERTS M. E., ABO A., TOMIZUKA K., FUNK W. D. 2006b. R-spondin proteins: a nowel link to the beta-catenin activation. Cell Cycle 5: 23-26.

Kocer A., Pinheiro I., Pannetier M., Renault L., PARMA P., RADI O., KIM K. A., CAMERINO G., PAILHOUXE. 2008. R-spondin1 and Foxl2 act into two distinct cellular types during goat ovarian differentiation. BMC Dev. Biol. 8: 36 .

LILLIE F. R. 1917. The freemartin: a study of the action of sex hormones in the foetal life of cattle. J. Exp. Zool. 23: 371-452.

MCLAREN A. 1984. Meiosis and differentiation of mouse germ cells. Symp. Soc. exp. Biol. 38: 7-23.

Menke D. B, PAgE D. C. 2002. Sexually dimorphic gene expression in the developing mouse gonad. Gene exp. Patterns 2: $359-367$.

MERCHANT H. 1975. Rat gonadal and ovarian organogenesis with and without germ cells. An ultrastructural study. Dev. Biol. 44: 1-21.

MizusaKi H., KAWABE K., MuKai T., ARIYOSHI E., KASAHARA M., YOSHIOKA H., SWAIN A., MOROHASI K. 2003. Dax-1 promoter is stimulated by SF-1 (steroidogenic factor-1) and inhibited by COUP-TF (chicken ovoalbumin upstream promoter-transcription factor) via a composite nuclear receptor-regulatory element. Mol. Endocrinol. 12: 1010-1022.

NAm J. S., Turcotte T. J., Smith P. F., Choi S., YoOn J. K. 2006. Mouse cristin/R-spondin family proteins are novel ligands for the Frizzled 8 and LRP6 receptors and activate beta-catenin-dependent gene expression. J. Biol. Chem. 281: 13247-13257.

Nef S., SchaAd O., Stallings N. R., Cederroth C. R., PITETTI J. L., SCHAER G., MALKI S., DUBOIS-DAUPHIN M., Boizet-Bonhoure B., Descombes P., PARKER K. L., VASSALLI J. D. 2005. Gene expression during sex determination reveals a robust female genetic program at the onset of ovarian development. Dev. Biol. 287: 361-377.

Osada M., Park H. L., Nagakawa Y., Begum S., YAMASHITA K., WU G. 2006. A novel response element confers $\mathrm{p} 63$ - and $\mathrm{p} 73$-specific activation of the WNT4 promoter. Biochem. Biophys. Res. Commun. 339: 1120-1128.

OtTOlenghi C., OMARI S., GARCiA-ORTIZ J. E., UdA M., CRISPONI L., Forabosco A., PILIA G., SCHLESSINGER D. 2005. Foxl2 is required for commitment to ovary differentiation. Hum. Mol. Genet. 14: 2053-2062.

Ottolenghi C., Pelosi E., Tran J., Colombino M., DOUGLASS E., NEDOREZOV T., CAO A., FORABOSCO A., SCHLESSINGER D. 2007. Loss of Wnt4 and Foxl2 leads to female-to-male sex reversal extending to germ cells. Hum. Mol. Genet. 16: 2795-2804.

Pailhoux E., Vigier B., Vaiman D., Servel N., ChaffauX S., CRIBIU E., COTINOT C. 2002. Ontogenesis of female-tomale sex-reversal in XX polled goats. Dev. Dyn. 224: 39-50.

PARMA P., RADI O., VidAl V., Chaboissier M. C., DEllamBRA E., VALENTINI S., GUERRA L., SCHEDL A., CAMERINO G. 2006. R-spondin1 is essential in sex determination, skin differentiation and malignancy. Nat. Genet. 38: 1304-1309.

Pinson K. I., Brennan J., MONKLEy S., AVERy B. J., SKARNES W. C. 2000. An LDL-receptor-related protein mediates Wnt signalling in mice. Nature 407: 535-538.

Polanco J. C., Koopman P. 2007. Sry and the hesitant beginnings of male development. Dev. Biol. 302: 13-24.

SCULLY R. E. 1979. Atlas of Tumor Pathology, second series, fascile 16: Tumors of the Ovary and Maldeveloped Gonads, The Armed Forces Institute of Pathology, Washington, DC.

Sim E. U., SMith A., SZILAGi E., RAE F., IOANNOU P., LindSAY M. H., LitTLE M. H. 2002. Wnt-4 regulation by the Wilms' tumour suppressor gene, WT1. Oncogene 21: 2948-2960.

Smith C. A., Shoemaker C. M., RoEsZLeR K. N., QueEN J., CREWS D., SINCLAIR A. H. 2008. Cloning and expression of $\mathrm{R}$-spondin 1 in different vertebrates suggests a conserved role in ovarian development. BMC Dev. Biol. 8: 72-87.

SOYAl S. M., AMLEH A., DEAN J. 2000. FIGalpha, a germ cell-specific transcription factor required for ovarian follicle formation. Development 127: 4645-4654.

Stark K., VAinio S., VASSILEVA G., MCMAHON A. P. 1994. Epithelial transformation of metanephric mesenchyme in the developing kidney regulated by Wnt4. Nature 372: 679-683.

TAKeto T., Koide S. S., Merchant-Larios H. 1984. Induction of testicular development in the fetal mouse ovary. Ann. N.Y. Acad. Sci. 438: 671-674.

TAKETO-Hosotani T., MERChant-LaRios H., THaU R. B., KOIDE S. S. 1985. Testicular cell differentiation in fetal mouse ovaries following transplantation into adult male mice. J. Exp. Zool. 236: 229-237.

TAShiro E., Minato Y., Maruki H., Asagiri M., Imoto M. 2003. Regulation of FGF receptor-2 expression by transcription factor E2F-1. Oncogene 22: 5630-5635.

TILMANN C., CAPEL B. 1999. Mesonephric cell migration induces testis cord formation and Sertoli cell differentiation in the mammalian gonad. Development 126: 2883-2890.

TOMaselli S., MEgiorni F., DE BERnARdo C., Felici A., Marrocco G., MaggiUlli G., Grammatico B., 
REMOTTI D., SACCUCCI P., VALENitni F., MAZZILli M. C., Majore S., GRAMmatico P. 2008. Syndromic true hermaphroditism due to an R-spondin1 (RSPO1) homozygous mutation. Hum. Mutat. 29: 220-226.

TOMizUKa K., HoriKoshi K., Kitada R., SUgawara Y., IBA Y., KoJIMA A., YOSHITOME A., YAMAWAKI K., AMAGai M., InOUE A., Oshima T., KaKitani M. 2008. Rspondin1 plays an essential role in ovarian development through positively regulating Wnt-4 signaling. Hum. Mol. Genet. 17: 1278-1291.

Uda M., OtTolenghi C., CRisponi L., Garcia J., Deiana M., Kimber W., Forabosco A., CAO A., SCHLESSinger D., PILIA G. 2004. Foxl2 disruption causes mouse ovarian failure by pervasive blockage of follicle development. Hum. Mol. Genet. 13: 1171-1181.

WIEACKER P., VOLLETH M. 2007. WNT4 and RSPO1 are not involved in a case of male-to-female sex reversal with partial duplication of 1p. Sex. Dev. 1: 111-113.
VAINIO S., HEIKKILA M., KisPERT A., CHIN N., MCMAHON A. P. 1999. Female development in mammals is regulated by Wnt-4 signaling. Nature 397: 405-409.

YAO H. H. 2005. The pathway to femaleness: current knowledge on embryonic development of the ovary. Mol. Cell. Endocrinol. 230: 87-93.

YAO H.H., DinAPOLI L., CAPEL B. 2003. Meiotic germ cells antagonize mesonephric cell migration and testis cord formation in mouse gonads. Development 130: 5895-5902.

Yao H. H., Matzuk M. M., JoRgez C. J., Menke D. B., PAGE D. C., Swain A., CAPEL B. 2004. Follistatin operates downstream of Wnt4 in mammalian ovary organogenesis. Dev. Dyn. 230: 210-215.

ZORN A. M., BARISH G. D., Williams B. O., LAVENDER P., KLYMKOWSKY M. W., VARMUS H. E. 1999. Regulation of Wnt signalling by Sox proteins: XSox17 alpha/beta and XSox3 physically interact with beta-catenin. Mol. Cell 4: 487-498. 